\title{
Osteogenic differentiation of adipose tissue-derived mesenchymal stem cells cultured with different concentrations of prolactin
}

[Diferenciação osteogênica de células tronco mesenquimais do tecido adiposo cultivadas com diferentes concentrações de prolactina]

\author{
K.P. Oliveira ${ }^{l}$, A.M.S. Reis ${ }^{l}$, A.P. Silva ${ }^{1}$, C.L.R. Silva ${ }^{1}$, A.M. Goes ${ }^{2}$, R. Serakides ${ }^{1}$, N.M. Ocarino ${ }^{1}$ \\ ${ }^{1}$ Escola de Veterinária - Universidade Federal de Minas Gerais - Belo Horizonte, MG \\ ${ }^{2}$ Instituto de Ciências Biológicas - Universidade Federal de Minas Gerais - Belo Horizonte, MG
}

\begin{abstract}
The objective was to evaluate the in vitro effect of prolactin in osteogenic potential of adipose tissue-derived mesenchymal stem cells (ADSCs) in female rats. ADSCs were cultured in osteogenic medium with and without the addition of prolactin and distributed into three groups: 1) ADSCs (control), 2) ADSCs with addition of $100 \mathrm{ng} / \mathrm{mL}$ of prolactin and 3) ADSCs with addition of $300 \mathrm{ng} / \mathrm{mL}$ of prolactin. At 21 days of differentiation, the tests of MTT conversion into formazan crystals, percentage of mineralized nodules and cells per field and quantification of genic transcript for alkaline phosphatase, osteopontin, osteocalcin, bone sialoprotein, BMP-2 and collagen I by real-time RT-PCR were made. The addition of prolactin reduced the conversion of MTT in group 3 and increased the percentage of cells per field in the groups 2 and 3, however without significantly increasing the percentage of mineralized nodules and the expression of alkaline phosphatase, osteopontin, osteocalcin, bone sialoprotein, BMP-2 and collagen I. In conclusion, the addition of prolactin in concentrations of $100 \mathrm{ng} / \mathrm{mL}$ and $300 \mathrm{ng} / \mathrm{mL}$ does not change the osteogenic differentiation to the ADSCs of female rats despite increase in the cellularity of the culture.
\end{abstract}

Keywords: rat, osteogenic differentiation, osteoblasts, hormone, adipose tissue

\section{RESUMO}

O objetivo do presente trabalho foi avaliar o efeito in vitro da prolactina sobre o potencial osteogênico de células-tronco mesenquimais do tecido adiposo (CTM-TA) em ratas. CTM-TA foram cultivadas em meio osteogênico com e sem adição de prolactina e distribuídas em três grupos: 1) CTM-TA (controle), 2) CM-TA com adição de $100 \mathrm{ng} / \mathrm{mL}$ de prolactina e 3) CTM-TA com adição de $300 \mathrm{ng} / \mathrm{mL}$ de prolactina. Aos 21 dias de diferenciação, foram realizados os testes de conversão do MTT em cristais de formazan, porcentagem de nódulos mineralizados e células por campo e quantificação dos transcritos gênicos para fosfatase alcalina, osteopontina, osteocalcina, sialoproteína óssea, BMP-2 e colágeno I. A adição de prolactina reduziu a conversão do MTT no grupo 3 e aumentou a porcentagem de células por campo nos grupos 2 e 3, sem alterar significativamente a porcentagem de nódulos mineralizados e a expressão de fosfatase alcalina, osteopontina, osteocalcina, sialoproteína óssea, BMP-2 e colágeno I. Conclui-se que a adição de prolactina nas concentrações de $100 \mathrm{ng} / \mathrm{mL}$ e 300ng/mL não altera a diferenciação osteogênica das CTM-TA de ratas, apesar do aumento de celularidade da cultura.

Palavras-chave: rato, diferenciação osteogênica, osteoblastos, hormônio, tecido adiposo

\section{INTRODUCTION}

The physiological hyperprolactinemia that occurs during pregnancy and lactation has been associated to bone loss in women and animals (Zuni et al., 1999; Coss et al., 2000; Dolinska et

Recebido em 22 de agosto de 2016

Aceito em 19 de janeiro de 2017

*Autor para correspondência (corresponding author)

E-mail: nataliaocarino@gmail.com al., 2010), with significant reduction of bone mineral density. The bone mass reduction observed in pregnant women varies from $2.1 \%$ to $9.4 \%$ in backbone; $0.9 \%$ to $3.9 \%$ in hip and approximately $2 \%$ to $4 \%$ in the radius (Karlsson et al., 2001). At lactation, bone losses were described between $0.4 \%$ and $7.5 \%$ in lumbar 
vertebrae, $2 \%$ to $5 \%$ in the femur and $0.2 \%$ to $7 \%$ in the radius (Karlsson et al., 2001; Karlsson et al., 2005). Young women with high blood levels of prolactin present bone mineral density similar to women in post-menopause (Alder et al., 1998) and individuals with high levels of prolactin, arising from prolactinoma, also show an increase of bone metabolism with consequent bone loss (Colao et al., 2000). But, it is probable that the effect of prolactin is dependent of their concentrations and the cell type on which is acting. This is because, contrary to the research where the increase of prolactin is associated to osteopenia (Alder et al., 1998; Colao et al., 2000), research with cells of osteosarcoma, cells that present receptors for prolactin, cultivated with prolactin demonstrated increase in osteoblastic activity (Bataille-Simoneau et al., 1996).

The genesis of osteopenia resulting from hyperprolactinemia has not been completely elucidated. Studies with addition of different concentrations of prolactin in cultures of osteoblasts, cells that express receptors for this hormone (Charoenphandhu et al., 2007), have demonstrated conflicting results, and there is either increased expression of genes of osteogenic differentiation such as RUNX-2, alkaline phosphatase, osteocalcin or decrease in the expression of these genes (Charoenphandhu et al., 2008; Seriwatanachai et al., 2009). Some researchers demonstrate that the bone loss due to increased bone reabsorption, arising from hypersecretion of prolactin, is mediated by estrogen deficiency (Biller et al., 1992; Naliato et al., 2005). This assertion has already been refuted since women with hyperprolactinemia do not present improvement of bone changes after restoration of gonadal endocrine function (Klibanski et al., 1988; Schlechte et al., 1992). It is possible that osteopenia originated from excess prolactin is caused by the reduction in the synthesis of bone matrix, since in female rats towards the end of the lactation there is hypoplasia and hypotrophy of osteoblasts (unpublished data). As the osteoblasts are originated from mesenchymal stem cells (MSC), the reduction of its number in the bones of female rats in lactation fosters the hypothesis of this study that the osteopenia, originated from the excess of prolactin, could be result of its effect on the osteogenic differentiation of mesenchymal stem cells.
Multiple studies have already demonstrated the participation of mesenchymal stem cells in the genesis of osteopenia induced by endocrine diseases such as hypo and hyperthyroidism (Boeloni et al., 2010; Boeloni et al., 2013a; Boeloni et al., 2013b; Boeloni et al., 2013c; Boeloni et al., 2015) and diabetes (Zhao et al., 2013; Ha et al., 2015). Although receptors for prolactin have already been identified in human mesenchymal stem cells, this seems to be the first study that investigated the effects of prolactin in the osteogenic differentiation of adipose tissue-derived mesenchymal stem cells. Thus, the objective of this study was to evaluate, under the osteogenic differentiation of ADSCs, two concentrations of prolactin that mimic the ones found in the blood of pregnant and lactanting female rats in order to infer on the isolated involvement of this hormone in the ADSCs.

\section{MATERIAL AND METHODS}

Three 45-days-old female Wistar rats (Rattus norvegicus) were used. The rats were euthanized with an overdose of an association of intraperitoneal anesthetic. All described procedures were approved by the Ethics Committee in Animal Experimenting at Universidade Federal de Minas Gerais (UFMG) (protocol 378/2012).

Immediately after the euthanasia, the extraction of ADSCswas performed according to the protocols already established (Zuk et al., 2002; Gomide et al., 2011). The visceral adipose tissue was collected aseptically in a laminar flow in Dulbecco's modified Eagle's medium (DMEM; Gibco, Grand Island, N.Y., USA) plus antibiotics and antimycotics $(60 \mu \mathrm{g} / \mathrm{L}$ gentamicine, $25 \mu \mathrm{g} / \mathrm{L}$ amphotericin B, $100 \mathrm{U} / \mathrm{mL}$ penicillin and $100 \mu \mathrm{g} / \mathrm{mL}$ streptomycin, Merck, Germany). The tissue was cut into small fragments, transferred to a tube containing $0.15 \%$ collagenase (Collagenase Type I, Gibco, Grand Island, N.Y., USA) diluted in $0.15 \mathrm{M}$ phosphate buffer solution (PBS) standard and incubated for 60 minutes at $37^{\circ} \mathrm{C}$ and $5 \% \mathrm{CO}_{2}$, shaking it every 15 minutes. Afterwards, it was centrifuged for 10 minutes at $1400 \mathrm{~g}$. The supernatant was discarded and the precipitate was resuspended in DMEM supplemented with antibiotics, antimycotics and $10 \%$ fetal bovine serum and collected in $75-\mathrm{cm}^{2}$ 
culture flasks in an oven at $37^{\circ} \mathrm{C}$ and $5 \% \mathrm{CO}_{2}$. The culture medium was changed twice a week. Cells cultured until the third passage in DMEM were trypsinized and centrifuged at $1400 \mathrm{~g}$ for 10 minutes. The cells were re-suspended at a concentration of $1 \times 10^{6}$ cells in PBS and transferred to 96-well plates with primary antibody for 30 minutes at $4^{\circ} \mathrm{C}$. The cells were washed with PBS and incubated with a secondary antibody conjugated with fluorescent (Alexa Fluor 488, Molecular Probes TO, OR, USA) for 30 minutes at $4^{\circ} \mathrm{C}$. The samples were analyzed using a cytometer FACScan (Becton Dickinson, NY, USA) and the data were analyzed using Cellquest software Becton Dickinson. The following primary antibodies were used: anti-CD45 (clone 69 mouse), antiCD90 (clone Ox-7 mouse), anti-CD73 (clone 5 F/B9 mouse) and anti-CD54 (clone 1A29 mouse) (BD Biosciences, San Jose, CA, USA).

After the initial culture in DMEM and four passages obtaining confluence of 80 to $90 \%$, the adherent cells were counted and trypsinized, distributed in six and 24 wells and in $25-\mathrm{cm}^{2}$ culture flasks $\left(1 \mathrm{x} \quad 10^{4}\right.$ cells $\left./ \mathrm{cm}^{2}\right)$. The basic medium was replaced through osteogenic medium, which consisted of DMEM added of antibiotics, antimycotics, $10 \%$ of fetal bovine serum plus $50 \mu \mathrm{g} / \mathrm{mL}$ ascorbic acid, $10 \mathrm{mM} \beta-$ glycerophosphate (Merck, Germany) and 10nM dexamethasone (Sigma-Aldrich, St. Louis, MO, USA). After the addition of the osteogenic medium, three experimental groups were formed with the addition of different concentrations of prolactin (Prolactin human, Sigma Aldrich, St Louis, MO, USA): 1) ADSCs (control), 2) ADSCs with addition of $100 \mathrm{ng} / \mathrm{mL}$ of prolactin and 3) ADSCs with addition of $300 \mathrm{ng} / \mathrm{mL}$ of prolactin. The cells were cultivated in oven with $5 \% \mathrm{CO}_{2}$ at $37^{\circ} \mathrm{C}$. The concentrations of prolactin were determined according to studies carried out by Seriwatanachai et al (2009) and Ritchie et al (1998) and are values that mimic those achieved during gestation and lactation of female rats respectively. At 21 days of differentiation, the tests of MTT conversion into formazan crystals, percentage of mineralized nodules and cells per field and quantification of alkaline phosphatase, osteopontin, osteocalcin, bone sialoprotein, BMP-2 and collagen I by real-time RT-PCR were made.
For each experimental group, $1 \times 10^{4}$ ADSCs $/ \mathrm{cm}^{2}$ was cultivated in 24-well plate with osteogenic medium with and without addition of prolactin. At the end of 21 days, the cultures were submitted to test for the conversion of the MTT \{bromide [3-(4,5-dimethylthiazol-2il)-2,5diphenyl tetrazolium]\} in formazan crystals. The medium was replaced by $210 \mu \mathrm{L}$ of osteogenic medium in each well and $170 \mu \mathrm{L}$ of MTT (5 $\mathrm{mg} / \mathrm{mL}$ ) (Invitrogen, Carlsbad, CA, USA). The plate was incubated for two hours in the oven at $37^{\circ} \mathrm{C}$ and $5 \% \mathrm{CO} 2$. The formazan crystals were observed under the microscope. Before, $210 \mu \mathrm{L}$ of sodium dodecyl sulphate (SDS) with $10 \% \mathrm{HCl}$ were added which remained overnight in the oven at $37^{\circ} \mathrm{C}$ and $5 \% \mathrm{CO}_{2}$. Subsequently, 100 $\mu \mathrm{L} /$ well were transferred to $96-$ well plate for analysis with wavelength of $595 \mathrm{~nm}$. The mean and standard deviation were determined for each experimental group. The tests were carried out in triplicate.

Briefly, for each experimental group, $1 \times 10^{4} \mathrm{ADSCs} / \mathrm{cm}^{2}$ was cultivated in 6-well plates with sterile cover slips. After 21 days, the wells were washed in PBS, cove slips fixed in $4 \%$ paraformaldehyde for 24 hours and subsequently rinsed in distilled water. After being added the silver nitrate solution at $5 \%$ (silver nitrate P.A. LabSynth, São Paulo, Brazil) the wells were exposed to light for two hours. The plates were washed with distilled water and the residual silver nitrate was neutralized by a solution of $5 \%$ sodium thiosulphate (sodium thiosulphate P.A. LabSynth, São Paulo, Brazil). The cells were counted and stained with eosin. The percentage of the mineralized nodules and cells per field were assessed by light microcopy and were quantified in 40 fields using an ocular piece containing a 121-point grid (Zeiss KPL, 10x) with a 10x magnification. The mean and standard deviation were determined for each experimental group. The tests were carried out in triplicate.

The quantification of the relative genic expression of alkaline phosphatase, osteopontin, osteocalcin, bone sialoprotein, BMP-2, collagen I in the ADSCs was compared between the three experimental groups with 21 days of differentiation. The extraction of total RNA of cells was done in three $25-\mathrm{cm}^{2}$ culture flasks per group by using Trizol (Life Technologies, CA, USA). The extraction method consisted of an initial step lysis and homogenization of the cell 
monolayer for five minutes at room temperature, for complete decoupling of nucleoprotein complexes. The lysate was transferred to a microtube of $1.5 \mathrm{~mL}$ and $0.2 \mathrm{~mL}$ was added with chloroform, followed by 10 seconds of homogenization, three minutes of incubation at room temperature and centrifuged at $12,000 \mathrm{~g}$ for 15 minutes at $4^{\circ} \mathrm{C}$, for separation into three stages. The aqueous phase was transferred to a new tube, with the addition of $0.5 \mathrm{~mL}$ of isopropyl alcohol and incubated for 30 minutes at a temperature of $-80^{\circ} \mathrm{C}$, followed by centrifugation at $12,000 \mathrm{~g}$ for 10 minutes to $4^{\circ} \mathrm{C}$ to precipitation of RNA. The pellet was then washed with $1 \mathrm{~mL}$ of ethanol $75 \%$, homogenized and centrifuged at $10,500 \mathrm{~g}$ for five minutes at $4^{\circ} \mathrm{C}$. The RNA was solubilized in DEPC water (water treated with dimethyl pirocarbonate, Invitrogen, Carlsbad, CA, USA) free of RNAse, incubated at $56^{\circ} \mathrm{C}$ in a thermoblock for 10 minutes and immediately stored at $-80^{\circ} \mathrm{C}$. The RNA concentration of each group was determined by the absorbance reading at 260/280nm by spectrophotometry. Reverse transcription reactions were performed using commercial kit (SuperScriptTM III Platinum $®$ Two-Step qRT-PCR Kit with SYBR Green, Invitrogen, CA, USA), being that it was used 1 $\mu \mathrm{g}$ of total RNA for cDNA synthesis with a final volume of $20 \mu \mathrm{L}$. It was still performed, the real time PCR reactions using $2 \mu \mathrm{L}$ of cDNA, $5 \mathrm{pM}$ of each primer and $12.5 \mu \mathrm{L}$ of reagent syber Green (SuperScriptTM III Platinum ${ }^{\circledR}$ Two-Step qRTPCR Kit with SYBR Green, Invitrogen, CA, USA) in a final volume of $25 \mu \mathrm{L}$ of reaction, at the equipment SmartCycler System (SmartCycler® System, Cepheid, Sunnyvale, CA, USA). The parameters used for amplification were: $50^{\circ} \mathrm{C}$ for 120 seconds, $95^{\circ} \mathrm{C}$ for 150 seconds and 45 cycles of $95^{\circ} \mathrm{C}$ for 15 seconds and $60^{\circ} \mathrm{C}$ for 30 seconds. The primers were designed based on the sequencing of the mRNA Rattus norvegicus (Table 1). The gene expression, the mean and standard deviation were determined in triplicate for each experimental group using the method $2^{-\Delta \Delta C T}$, in which the results obtained for each group were compared quantitatively after normalization based on the expression of GAPDH Rattus norvegicus.

The experimental design was completely randomized. A variance analysis was performed (ANOVA) and, for each variable, the means and the standard deviation were determined. The means were compared by the SNK test (StudentNewman-Keuls) using the Graphpad Instat 3.05 (GraphPad Software Inc., San Diego, USA). The changes in the expression measured by real-time RT-PCR were compared by the SNK test. Differences were considered significant if $\mathrm{P}<0.05$.

Table 1. List of genes and nucleotide sequence of the primers for RT-PCR in real time

\begin{tabular}{llc}
\multicolumn{1}{c}{ Gene } & \multicolumn{1}{c}{ Primers $\left(5^{\prime}{ }^{\prime}-3^{\prime}\right)$} & Acess \\
Alkaline phosphatase & $\begin{array}{l}\text { forward: CTAGTTCCTGGGAGATGGTA } \\
\text { reverse: GTGTTGTACGTCTTGGAGAGA }\end{array}$ & NM 013059.1 \\
\hline Osteopontin & $\begin{array}{l}\text { foward: ATCTCACCATTCCGATGAATCT } \\
\text { reverse: TCAGTCCATAAGCCAAGCTATCA }\end{array}$ & AB 001382 \\
\hline Osteocalcin & $\begin{array}{l}\text { foward: CATCTATGGCACCACCGTTT } \\
\text { reverse: AGAGAGAGGGAACAGGGAGG }\end{array}$ & NM 013414.1 \\
& $\begin{array}{l}\text { foward: TGTCCTTCTGAACGGGTTTC } \\
\text { reverse: CTTCCCCATACTCAACCGTG }\end{array}$ & NM 012587.2 \\
\hline BMP-2 & $\begin{array}{l}\text { foward: TAGTGACTTTTGGCC ACGACG } \\
\text { reverse: GCTTCCGCTGTTTGTGTTTG }\end{array}$ & NM 017178 \\
\hline Collagen I & $\begin{array}{l}\text { foward: GCAAGGTGTTGTGCGATGACG } \\
\text { reverse: GGGAGACCACGAGGACCAGAG }\end{array}$ & NM 000088 \\
\hline GAPDH & $\begin{array}{l}\text { foward: CAACTCCCTCAAGATTGTCAGCAA } \\
\text { reverse: GGCATGGACTGTGGTCATGA }\end{array}$ & NM 002046 \\
\hline
\end{tabular}




\section{RESULTS}

The cells extracted from the adipose tissue showed phenotypic characteristics compatible with mesenchymal stem cells, i.e. $90.26 \%$ of cells presented expression for CD90, $99.24 \%$ of cells presented expression for CD73, 91.90\% of cells presented for CD54 expression and only $3.04 \%$ of cells presented for CD45 expression.

The group of ADSCs differentiated with addition of $300 \mathrm{ng} / \mathrm{mL}$ presented minor conversion of
MTT as compared to control. The group 2 presented no difference when compared to the control group (Figure 1).

The addition of prolactin in the osteogenic medium promoted positive effect significantly increasing the percentage of cells in the groups $100 \mathrm{ng} / \mathrm{mL}$ and $300 \mathrm{ng} / \mathrm{mL}$ in relation to the control group. However, there was no difference in the percentage of mineralized nodules between the groups that received prolactin and the control group (Figure 1).
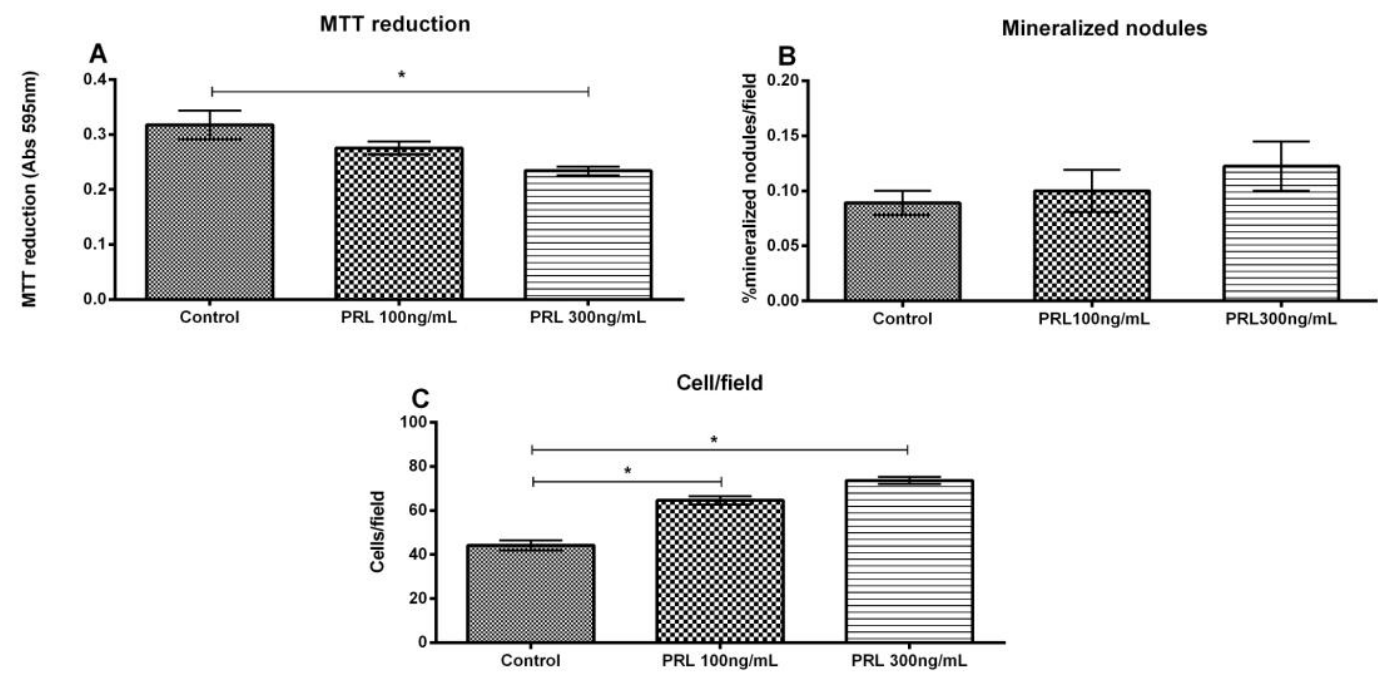

Figure 1. ADSCs cultured in osteogenic medium with and without addition of prolactin after 21 days of differentiation. A) MTT reduction into formazan crystals (mean \pm SD absorbance at $595 \mathrm{~nm}$ ). B) Percentage of mineralized nodules (mean $\pm \mathrm{SD}$ ) and $\mathrm{C}$ ) percentage of cells per field (mean $\pm \mathrm{SD}$ ). ${ }^{*} \mathrm{P}<0.05$.

The addition of prolactin in the osteogenic medium did not alter the relative expression of gene transcripts for alkaline phosphatase, osteopontin, osteocalcin, bone sialoprotein, BMP-2, collagen I when compared to the control group (Figure 2).

\section{DISCUSSION}

The phenotypical characterization showed that the cells used presented characteristics compatible with the mesenchymal stem cells, i.e., more than $90 \%$ of the cells presented expression of surface for CD90, CD73 and CD54 and less than $5 \%$ presented marking for CD45 that is expressed by hematopoietic cells. These results comply with what is recommended by International Society for Cellular Therapy assuring that the experiment was performed with culture of stem cells. This characterization is important because the vascular stromal fraction extracted from the adipose tissue contains beyond the ADSCs, other cell types such as endothelial cells, fibroblasts and hematopoietic cells (Dominici et al., 2006).

The prolactin in the concentration of $300 \mathrm{ng} / \mathrm{mL}$ reduced the conversion of MTT of formazan crystals even having increased cellularity, characterized by increasing the percentage of cells per field. The assay of dimethylthiazol (MTT) is a quantitative colorimetric method that is based on the capacity of succinate dehydrogenase, an enzyme active in mitochondria, in converting the water-soluble salts of the tetrazolium. This assay is dependent 
of mitochondrial metabolism. The MTT assay has been used to evaluate the cellular viability (Berridge et al., 2005). However, in the present study, it can not be said that the concentration of $300 \mathrm{ng} / \mathrm{mL}$ of the prolactin has reduced the cellular viability, since the percentage of
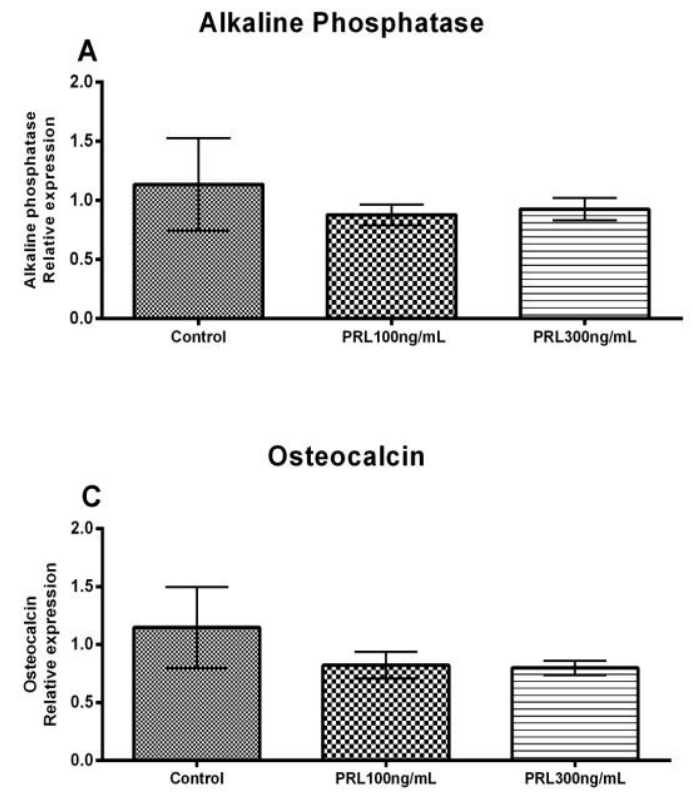

BMP-2

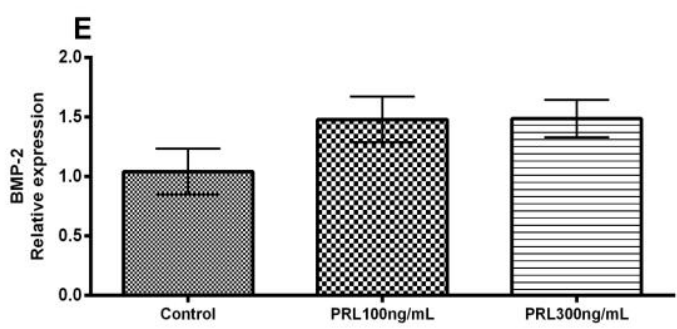

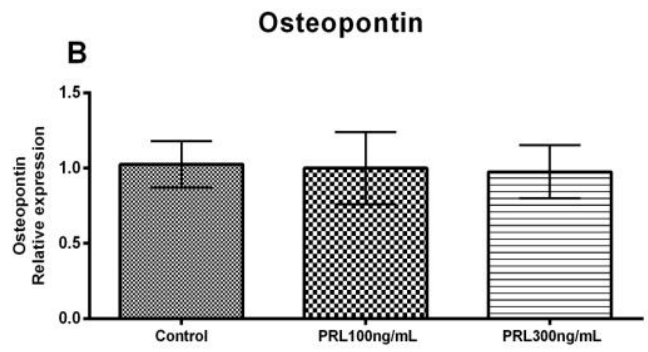

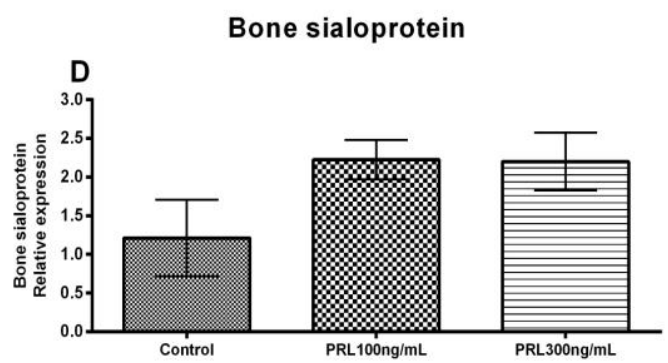

cells/field was significantly higher than control. MTT assay does not determine if the increase in the percentage of cells observed in the ADSCs with addition of $300 \mathrm{ng} / \mathrm{mL}$ of prolactin was due to increased cell proliferation or decreased apoptosis.

Bone sialoprotein

Collagen I

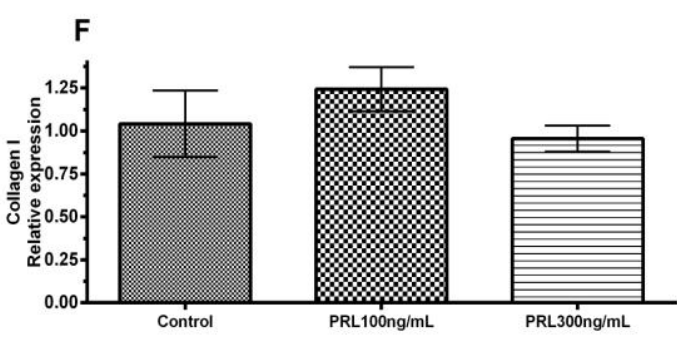

Figure 2. The relative quantification (mean $\pm \mathrm{SD}$ ) of genes expression via real-time RT-PCR of the ADSCs cultured in osteogenic medium with and without addition of prolactin after 21 days of differentiation. $* \mathrm{P}<0.05$. A) Alkaline phosphatase, B) Osteopontin, C) Osteocalcin, D) Bone sialoprotein, (E) BMP-2 and (F) Collagen I.

The addition of prolactin in the culture of ADSCs in the two studied concentrations did not alter the expression of genic transcripts of osteogenic differentiation as well as the formation of the mineralized nodules. More studies are needed to verify if the addition of prolactin in vitro would not change the production of protein resulting from the expression of such genic transcripts. However, it is likely that there is no difference between groups in the protein expression too, once the synthesis of mineralized matrix did not differ significantly between groups.

The main factors that stimulate the differentiation of osteoprogenitor cells in the MSC have been studied. It is known that the proliferation and differentiation both in vitro as 
well as in vivo of MSC in osteoblasts are under the command of several factors (Lindblad, 2001) such as genes, growth factors, mechanical stimulus and some hormones (Payushina et al., 2006). These factors may act directly or indirectly in the various phases of osteogenic differentiation (Qu et al., 1998; Hughes et al., 2006) and little is known about the role of the PRL in each one of these steps and if such action is dose-dependent. Our results demonstrate that the action of prolactin in vitro on the MSC seems to be different from the action of this hormone in cultures of osteoblasts, despite of having been used concentrations similar to prolactin. The addition of prolactin in concentrations of 100 and $300 \mathrm{ng}$ increased cellularity, but did not promote significant changes of the parameters that allow us to evaluate the osteogenic differentiation of MSC, which suggests that the prolactin perhaps stimulates more the proliferative activity than the osteogenic differentiation of MSC. However, it cannot be ruled out that the reduction of osteogenic differentiation of the MSC is one of the mechanisms responsible for bone mass reduction observed in periods of hyperprolactinemia of gestation and lactation, since that in vivo, the hyperprolactinemia may have an indirect effect on the osteogenic differentiation of MSC for reducing concentrations of estrogen, progesterone and gonadotropin hormones these that have direct action and positive about the osteogenic differentiation of MSC (Qu et al., 1998; Dolinska et al., 2010; Grachev et al., 2015).

\section{CONCLUSION}

In conclusion, the addition of prolactin concentrations of $100 \mathrm{ng} / \mathrm{mL}$ and $300 \mathrm{ng} / \mathrm{mL}$ does not alter the osteogenic differentiation of ADSCs of female rats, despite increase of the cellularity of the culture.

\section{ACKNOWLEDGEMENTS}

This work was supported by grants from the Fundação de Amparo à Pesquisa de Minas Gerais (Fapemig) and Conselho Nacional de Desenvolvimento Científico e Tecnológico (CNPq).

\section{REFERENCES}

ALDER, R.A.; EVANI, R.; MANSOURI, A.; KRIEG Jr., R.J. Relative effects of prolactin excess and estrogen deficiency on bone in rats. Metabolismo, v.47, p.425-428, 1998.

BATAILLE-SIMONEAU, N.; GERLAND, K.; CHAPPARD, D. et al. Expression of prolactin receptors in human osteosarcoma cells. Biochem. Biophys. Res. Comm., v.229, p.323-328, 1996.

BERRIDGE, M.V.; HERST, P.M.; TAN, A.S. Tetrazolium dyes as tools in cell biology: new insights into their cellular reduction. Biotech. Ann. Rev., v.11, p.127-152, 2005.

BILLER, B.M.; BAUM, H.B.; ROSENTHAL, D.I. et al. Progressive trabecular osteopenia in woman with hyperprolactinemic amenorrhea. J. Clin. Endocrinol. Metab., v.75, p.692-697, 1992

BOELONI, J.N.; OCARINO, N.M.; GOES, A.M.; SERAKIDES, R. Efeito in vitro da triiodotironina sob o potencial osteogênico reduzido das células tronco mesenquimais do tecido adiposo de ratas ovariectomizadas e com osteoporose. Arq. Bras. Endocrinol. Metab., v.57, p.98-111, 2013a.

BOELONI, J.N.; OCARINO, N.M.; GOES, A.M.; SERAKIDES, R. In vitro effects of triiodothyronine on the reduced osteogenic potencial of bone marrow mesenchymal stem cells of rats with osteoporosis. Braz. J. Vet. Pathol., v.8, p.76-87, 2015.

BOELONI, J.N.; OCARINO, N.M.; GOES, A.M.; SERAKIDES, R. Triiodotironina não aumenta a diferenciação osteogênica reduzida pela idade de células tronco mesenquimais da medula óssea de ratas. Arq. Bras. Endocrinol. Metab., v.57, p.62-70, 2013b.

BOELONI, J.N.; OCARINO, N.M.; SILVA, J.F. et al. Osteogenic differentiation of bone marrow mesenchymal stem cells of ovariectomized and nonovariectomized female rats with thyroid dysfunction. Pathol. Res. Pract., v.209, p.44-51, 2013c.

BOELONI, J.N.; SILVA, J.F.; MAGALHÃES, F.C. et al. Efeitos sítio-ósseos dependentes no fêmur e vértebras de ratas com disfunções tireoidianas. Acta Ortop. Bras., v.18, p.291-294, 2010.

CHAROENPHANDHU, N.; TEERAPORNPUNTAKIT, J.; METHAWASIN, M. et al. Prolactin decreases expression of Runx2, osteoprotegerin, and RANKL in primary osteoblasts derived from tibiae of adult female rats. Can. J. Physiol. Pharmacol., v.86, p.240-248, 2008.

CHAROENPHANDHU, N.; TUDPOR, K.; THONGCHOTE, K. et al. High-calcium diet modulates effects of longterm prolactin expouse on the cortical bone calcium content in ovariectomized rat. Am. J. Endocrinol. Metab., v.292, p.443-452, 2007. 
COLAO, A.; DI SOMMA, C.; LOCHE, S. et al. Prolactinomas in adolescents: persistent bone loss after 2 years of prolactin normalization. Clin. Endocrinol., v.52, p.319-327, 2000.

COSS, D.; YANG, L.; KUO, C.B. et al. Effects of prolactin on osteoblast alkaline phosphatase and bone formation in the development rat. Am. J. Physiol. Endocrinol. Metab., v.279, p.1216-1225, 2000.

DOLINSKA, B.; SUSZKA-SWITEK, A.; DRAGAN, S. et al. The influence of prolactin on bone mineral density (BMD) and some biochemical markers of ovariectomized rats. J. Anim. Sci., v.55, p.83-88, 2010.

DOMINICI, M.; LE BLANC, K.; MUELLER, I. et al. Minimal criteria for defining multipotent mesenchymal stromal cells. The International Society for Cellular Therapy position statement. Cythoterapy, v.4, p.315-317, 2006.

GOMIDE, V.; ZONARI, A.A.C.; BREYNER, N.M. et al. Attachment and proliferation of human-adiposetissue-derived stem cells on bioactive glass/PVA hybrid scaffolds. Int. Scholary Res. Not. Mater. Sci., 2011.

GRACHEV, P.; LI, X.F.; GOFFIN, V.; O'BYRNE, K.T. Hypothalamic prolactin regulation of luteinizing hormone secretion in the female rat. Endocrinology, v.156, p.2880-2892, 2015.

HA, C.Z.; CHEN, H.Y.; WANG, J. et al. Effect of diabetic osteoblasts on osteogenic differentiation of human umbilical cord mesenchymal stem cells. Biomed. Pap. Med. Fac. Univ. Palacky Olomouc Czech Repub., v.159, p.388-393, 2015.

HUGHES, F.J.; TURNER, W.; BELIBASAKIS, G.; MARTUSCELLI, G. Effects of growth factors and cytokines on osteoblast differentiation. Periodontology, v.41, p.48-72, 2006.

KARLSSON, C.; OBRANT, KJ.; KARLSSON, M. Pregnancy and lactation confer reversible bone loss in humans. Osteoporos. Int., v.12, p.828-834, 2001.

KARLSSON, M.J.; AHLBORG, H.G.; KARLSSON, C. Female reproductive history and skeleton - a review. Br. J. Obstet. Gyneacol., v.112, p.851-856, 2005.
KLIBANSKI, A.; BILLER, B.M.; ROSENTHAL, D.I. et al. Effects of prolactin and estrogen deficiency in amenorrheic bone loss. J. Clin. Endocrinol. Metab., v.67, p.124-130, 1988.

LINDBLAD, W.J. Stem cells in mammalian repair and regeneration. Wound Repair Degen., v.9, p.423424, 2001.

NALIATO, E.C.; FARIAS, M.L.; BRAUCKS, G.R. et al. Prevalence of osteopenia in men with prolactinoma. J. Endocrinol. Invest., v 28, p.12-17, 2005.

PAYUSHINA, O.V.; DOMARATSKAYA, E.I.; STAROSTIN, V.I. Mesenchymal stem cells: sources, phenotype, and differentiation potential. Cell. Biol., v.33, p.6-25, 2006.

QU, Q.; PERALA-HAEPE, M.; KAPANE, A. et al. Estrogen enhances differentiation of osteoblasts in mouse bone marrow culture. Bone, v.22, p.201-209, 1998.

RITCHIE, L.D.; FUNG, E.B.; HALLORAN, B.P. et al. A longitudinal study of calcium homeostasis during human pregnancy and lactation and after resumption of menses. Am. J. Clin. Nutr., v.67, p.693-701, 1998.

SCHLECHTE, J.; WALKNER, L.; KATHOL, M.A. Longitudinal analysis of premenopausal bone loss in healthy women and women with hyperprolactinemia. J. Clin. Endocrinol. Metab., v.75, p.698-703,1992.

SERIWATANACHAI, D.; KRISHNAMRA, N.; VAN LEEUWEN, J.P.T.M. Evidence for direct effects of prolactin on human osteoblasts: Inhibition of cell growth and mineralization. J Cell Biochem., v.107, p.677-685, 2009.

ZHAO, Y.F.; ZENG, D.L.; XIA, L.G. et al. Osteogenic potential of bone marrow stromal cells derived from streptozotocin-induced diabetic rats. Int. J. Mol. Med., v.31, p.614-620, 2013.

ZUK, P.A.; ZHU, M.; ASHJIAN, P. et al. Human adipose tissue is a source of multipotent stem cells. Mol. Biol. Cell., v.13, p.4279-4295, 2002.

ZUNI, S.N.; DI GREGORIO, S.; MAUTALEN C. Bone mass changes during pregnancy and lactation in the rat. Bone, v.25, p.681-685. 1999. 